\title{
'Cannon ball' pulmonary metastases
}

\author{
Nischala Ammannagari, Vengamamba Polu
}

Department of Internal Medicine, Bassett Medical Center, Cooperstown, New York, USA

\section{Correspondence to} Dr Nischala Ammannagari, nischala.ammannagari@ bassett.org
To cite: Ammannagari $\mathrm{N}$, Polu V. BMJ Case Reports Published online: [please include Day Month Year] doi:10.1136/bcr-2012008158

\section{DESCRIPTION}

A 62-year-old woman, with no significant medical history, was found unresponsive at home. Patient was intubated and rushed to our emergency room. She was found to be in renal failure with hyperkalaemia. Chest x-ray (figure 1) revealed multiple large pulmonary nodules highly suggestive of pulmonary metastases. CT scan of the thorax (figure 2), abdomen and pelvis (figure 3) revealed a large pelvic mass contiguous with bladder, with bilateral hydronephrosis and multiple large pulmonary masses with cavitation. Biopsy of the pelvic mass confirmed the diagnosis of high-grade transi-

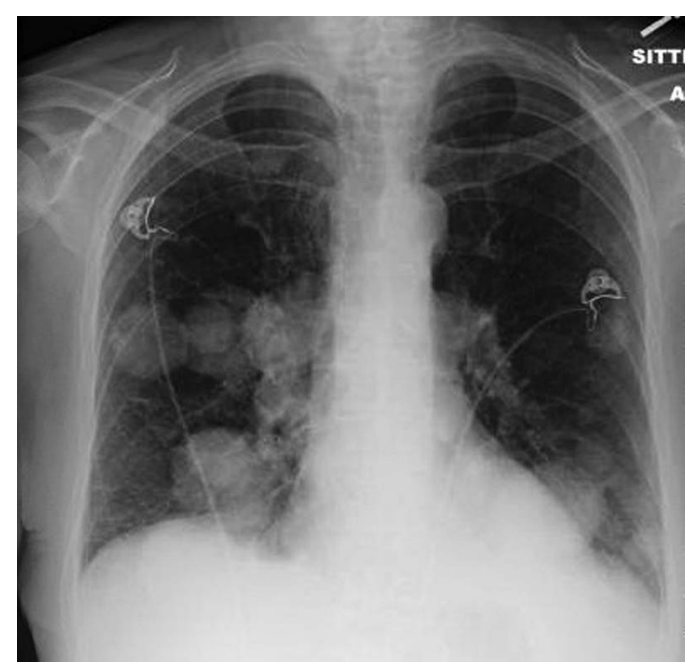

Figure 1 Chest x-ray showing multiple large 'cannon ball' pulmonary nodules.

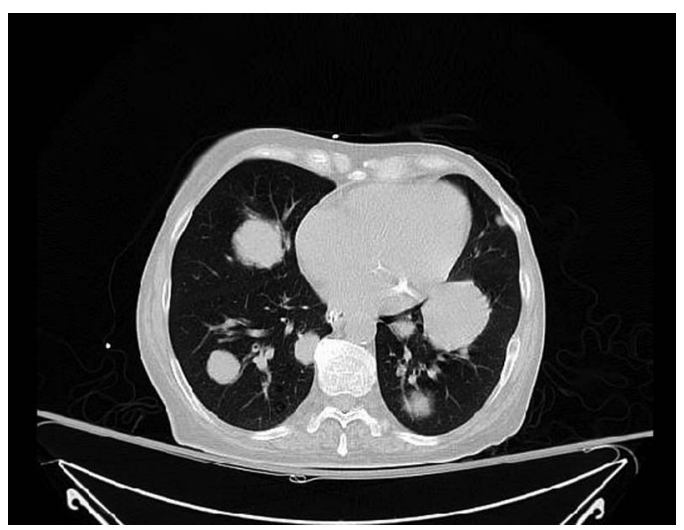

Figure $2 \mathrm{CT}$ thorax showing multiple large lung lesions with cavitation.

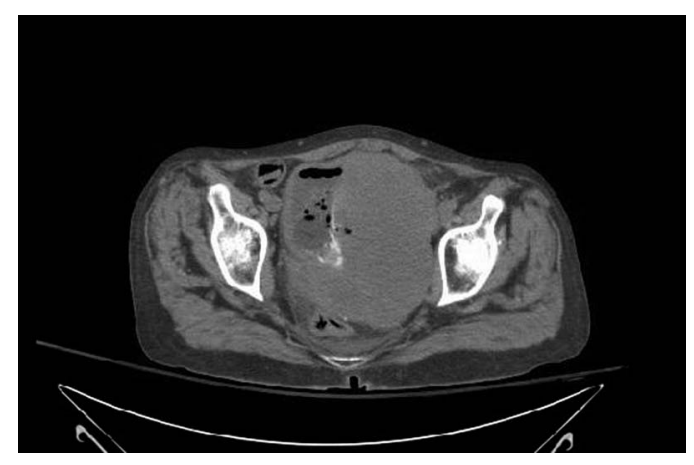

Figure $3 \mathrm{CT}$ abdomen and pelvis revealing large bladder mass.

tional cell carcinoma. Unfortunately, patient elected not to undergo any aggressive interventions including chemotherapy, and chose hospice and palliative care. She passed away 1 month after the diagnosis.

Large, round, well-circumscribed metastatic pulmonary nodules are called 'cannon ball' metastases. They are usually associated with disseminated malignancy. They indicate a poor prognosis although rarely few cases with favourable outcome have been reported. ${ }^{12}$ These are classically seen in renal cell carcinoma, also seen in chorio carcinoma, endometrial cancer, prostate cancer and some gastrointestinal malignancies. ${ }^{1}{ }^{2}$ However, association with bladder tumour is rare.

\section{Learning points}

- Large, round, well-circumscribed metastatic pulmonary nodules are called 'cannon ball' metastases.

- They are usually associated with disseminated malignancy and indicate grim prognosis.

Competing interests None.

Patient consent Obtained.

Provenance and peer review Not commissioned; externally peer reviewed.

\section{REFERENCES}

1 Nabi G, Sadiq M. Multiple bilateral cannon-ball lung metastases from carcinoma of the prostate: orchiedectomy induced remission. Med I Malaysia 2002;57:111-13.

2 Flavin R, Finn S, McErlean A, et al. Cannonball metastases with favorable prognosis. Ir J Med Sci 2005;174:61-4. 
Copyright 2013 BMJ Publishing Group. All rights reserved. For permission to reuse any of this content visit http://group.bmj.com/group/rights-licensing/permissions.

BMJ Case Report Fellows may re-use this article for personal use and teaching without any further permission.

Become a Fellow of BMJ Case Reports today and you can:

- Submit as many cases as you like

- Enjoy fast sympathetic peer review and rapid publication of accepted articles

- Access all the published articles

- Re-use any of the published material for personal use and teaching without further permission

For information on Institutional Fellowships contact consortiasales@bmjgroup.com

Visit casereports.bmj.com for more articles like this and to become a Fellow 